\title{
PLASMA NONESTERIFIED FATTY ACIDS IN HYPERTHYROID STATES
}

\author{
By CLAYTON RICH, EDWIN L. BIERMAN* AND IRVING L. SCHWARTZ $\dagger$ \\ (From The Rockefeller Institute for Medical Research, New York, N. Y.)
}

(Submitted for publication August 25, 1958; accepted September 18, 1958)

Adipose tissue appears to be more than normally active in hyperthyroidism. The low fasting respiratory quotient and increased oxygen consumption $(1,2)$ as well as the predisposition to ketosis (3) of hyperthyroid subjects suggest that mobilization and oxidation of fat are accelerated. This inference is supported by the finding of an increased rate of turnover of fatty acids of thyroidfed rats $(4,5)$.

Recent studies indicate that the nonesterified fatty acid fraction of plasma reflects the metabolic state of adipose tissue. The concentration of nonesterified fatty acids (NEFA) rises when energy is drawn from stored fat, as in fasting, uncontrolled diabetes and after epinephrine (6-8), and falls after administration of carbohydrate or insulin $(6,9)$. The fall after insulin administration has been related to diminished outflow of fatty acids from tissue stores (9-11). The sharp rise after epinephrine is probably due to action at the same site, since epinephrine causes an output of fatty acids from isolated adipose tissue (11). Thus the concentration of NEFA in plasma appears to be an index of the rate of mobilization of fat.

The present studies were undertaken to see if the altered fat metabolism of the hyperthyroid state would be reflected in changes of plasma NEFA concentration of patients with spontaneous hyperthyroidism and of euthyroid subjects treated with triiodothyronine during acute and long term experiments. In all subjects studied, the plasma NEFA concentration was found to be increased when the metabolic rate was elevated.

\section{PROCEDURE}

Group I. Measurements were made of plasma NEFA concentration (6) of plasma taken at about 9:30 a.m. (after an overnight fast) from nine patients with typical

* Present address: U.S.A. Medical Nutrition Laboratory, Fitzsimons Army Hospital, Denver, Colo.

$\dagger$ Present address: Medical Research Center, Brookhaven National Laboratory, Upton, Long Island, N. Y. thyrotoxicosis. The diagnosis was established in each case by characteristic signs and symptoms, including elevated basal metabolic rate and thyroidal radioiodine uptake.

Group II. Six euthyroid subjects (four obese, one with sarcoidosis and one with a parathyroid adenoma) were tested as follows: Two control blood samples were taken in the morning (after an overnight fast which lasted until completion of the test) and then either 1 or $2 \mathrm{mg}$. of L-triiodothyronine (TRITH) or $15 \mathrm{mg}$. of L-triiodothyroacetic acid (TRIAC) ${ }^{1}$ were given by vein and additional blood samples taken each hour for the next six hours. The basal metabolic rate was measured at the start of the test and after five and six hours. As a control, the procedure was carried out for each subject in the same way except that no medication was given. All samples were analyzed for NEFA, cholesterol (12) and glucose (13).

Group III. Seven euthyroid subjects hospitalized on the Infectious Disease Service were given TRITH as a therapeutic trial in the course of an unrelated study to be reported elsewhere. ${ }^{2}$ These patients received a daily dose of 0.15 to $0.2 \mathrm{mg}$. of TRITH orally for 30 to 40 day periods alternating with similar periods during which no TRITH was given. Blood samples, taken each week after an overnight fast, were analyzed for cholesterol and NEFA. The basal metabolic rate was measured every two to four days.

\section{Group I}

RESULTS

Fasting NEFA values of nine hyperthyroid patients averaged $1,103 \mu$ Eq. per L. with a standard deviation of $164 \mu \mathrm{Eq}$. per L. This average was

\footnotetext{
${ }^{1}$ L-Triiodothyronine (Cytomel ${ }^{\circledR}$ ) and L-triiodothyroacetic acid were very generously supplied by Smith, Kline and French Laboratories, Philadelphia, Pa.

2 These patients had moderately far advanced pulmonary tuberculosis. They were under continuous treatment with isoniazid ( $5 \mathrm{mg}$. per $\mathrm{Kg}$. per day) and streptomycin ( $1 \mathrm{Gm}$. three times per week). The effect of TRITH on the course of their disease was under investigation because of observations in animals that thyroil hormone increases resistance to pulmonary tuberculosis. We are indebted to Drs. D. Böhme, S. Osterhout, R. W. Schaedler, H. Simon and J. G. Hirsch for the opportunity to carry out metabolic studies on these patients during the period when treatment with TRITH was being evaluated.
} 


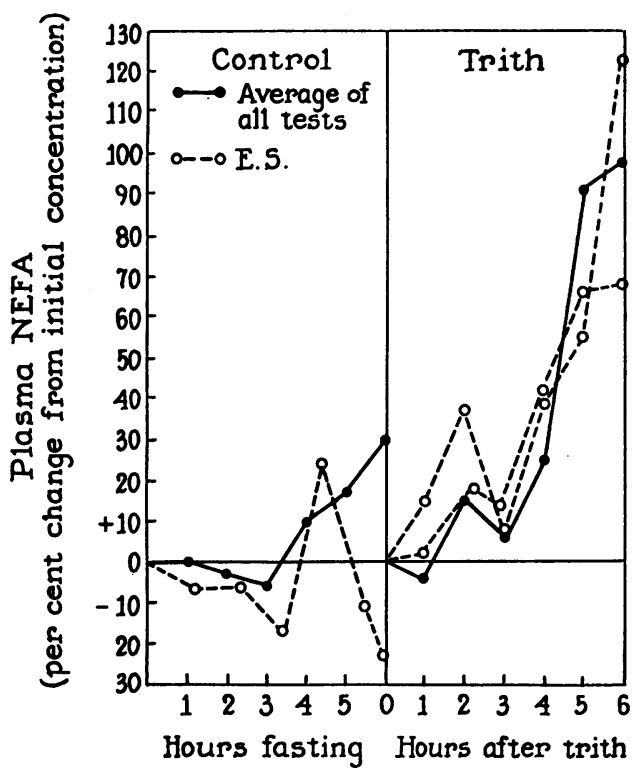

Fig. 1. Comparison of the Changes of the Concentration of Plasma of Nonesterified fatty Acids (NEFA) in Plasma During a Six Hour Period of Fasting (Control) and During a Similar Period AFter the INTRAVENOUS AdMinistration OF 1 OR 2 Mg. L-TRIIODOTHYRONINE (TRITH)

Solid lines indicate the mean for all subjects studied. Dashed lines compare the individual responses of a single subject (E. S.) during one control and two TRITH tests.

significantly greater (" $t$ " test, $p<0.01$ ) than the normal fasting value of $572 \pm 280 \mu \mathrm{Eq}$. per L. (8).

\section{Group II}

A total of 18 tests were made, 7 control, 7 in which 1 or $2 \mathrm{mg}$. of TRITH and 4 in which 15 mg. of TRIAC was given. NEFA concentration, but not the basal metabolic rate, usually rose slightly during the control test. In contrast, during the six hours after intravenous administration of TRITH, there was a sharp increase of NEFA concentration in every subject to reach values averaging $592 \pm 254 \mu \mathrm{Eq}$. per L. greater than the original values (Figure 1 ). This increase was significantly greater $(p<0.01)$ than that observed during the control test when no TRITH was given (Table I). After administration of TRITH, oxygen consumption rose significantly $(p<0.01)$ above control values, but no significant changes of glucose or cholesterol concentrations were observed (Table I). From about the eighth through the thirty-sixth hour after TRITH most subjects showed one or more of the following signs and symptoms of thyroid effect: tachycardia, nervousness, headache, rise in systolic pressure and, occasionally, rise in body temperature (less than $1^{\circ} \mathrm{C}$.).

Only one of the four subjects given $15 \mathrm{mg}$. TRIAC had any effect from this dose. The subject who did respond showed the same changes which were observed after TRITH: a sharp rise in NEFA and basal metabolic rate, but no alteration of either cholesterol or glucose concentration.

\section{Group III}

During the first week of treatment, all subjects given 0.15 or $0.20 \mathrm{mg}$. TRITH per day developed clinical signs of thyroid effects, with marked elevation of metabolic rate, fall of serum cholesterol and rise of NEFA (Figure 2). These effècts disappeared during the first 10 days after TRITH was discontinued and returned when it was given again. (A typical response is shown in Figure 3.) During the control period the mean of the plasma NEFA concentrations of all subjects in this group

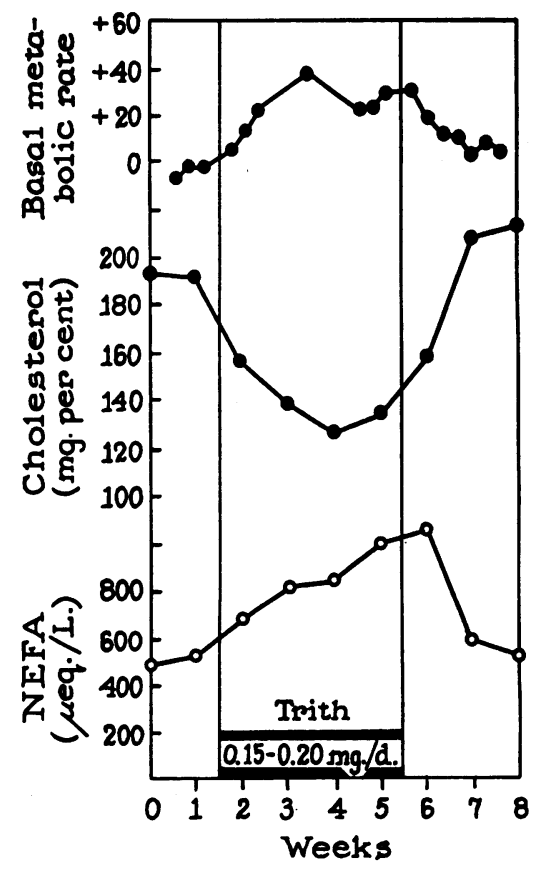

Fig. 2. Mean Changes of Plasma, Cholesterol and NEFA Concentrations and of Basal Metabolic Rates of Euthyroid Subjects Treated with L-TriodoTHYRONINE (TRITH) FOR ONE MONTH 
TABLE I

Comparison of changes produced during a six hour fast (control) and during a similar period after 1 or $2 \mathrm{mg}$. triiodothyronine (TRITH) by vein

\begin{tabular}{|c|c|c|c|c|c|}
\hline & \multirow[b]{2}{*}{ Test } & \multicolumn{2}{|c|}{$\begin{array}{l}\text { Mean value } \pm \text { S. D.* for } \\
\text { all subjects studied }\end{array}$} & \multirow{2}{*}{$\begin{array}{c}\text { Mean } \\
\text { difference } \\
\text { between } \\
\text { original and } \\
\text { final values }\end{array}$} & \multirow{2}{*}{$\begin{array}{c}\text { Significance } \\
\text { of difference } \\
\text { between contro } \\
\text { and TRITH } \\
\text { tests (p) }\end{array}$} \\
\hline & & $\begin{array}{c}\text { Start of } \\
\text { test }\end{array}$ & $\begin{array}{c}\text { End of } \\
\text { test }\end{array}$ & & \\
\hline $\begin{array}{l}\text { Plasma NEFA } \\
\mu E q . / L\end{array}$ & $\begin{array}{l}\text { Control } \\
\text { TRITH }\end{array}$ & $\begin{array}{l}855 \pm 243 \\
768 \pm 214\end{array}$ & $\begin{array}{r}873 \pm 128 \\
1,360 \pm 306\end{array}$ & $\begin{array}{l}+18 \\
+592\end{array}$ & $<0.01$ \\
\hline $\begin{array}{l}\text { Oxygen consumption } \\
\text { ml./min. }\end{array}$ & $\begin{array}{l}\text { Control } \\
\text { TRITH }\end{array}$ & $\begin{array}{l}245 \pm 24 \\
231 \pm 27\end{array}$ & $\begin{array}{l}241 \pm 17 \\
275 \pm 41\end{array}$ & $\begin{array}{r}-4 \\
+44\end{array}$ & $<0.01$ \\
\hline $\begin{array}{l}\text { Plasma glucose } \\
\text { mg./100 ml. }\end{array}$ & $\begin{array}{l}\text { Control } \\
\text { TRITH }\end{array}$ & $\begin{array}{l}70.8 \pm 8.4 \\
77.2 \pm 6.7\end{array}$ & $\begin{array}{l}74.3 \pm 10.0 \\
77.0 \pm 5.9\end{array}$ & $\begin{array}{l}-3.7 \\
-0.2\end{array}$ & $>0.5$ \\
\hline $\begin{array}{l}\text { Serum cholesterol } \\
\text { mg./100 ml. }\end{array}$ & $\begin{array}{l}\text { Control } \\
\text { TRITH }\end{array}$ & $\begin{array}{l}161 \pm 24 \\
189 \pm 30\end{array}$ & $\begin{array}{l}161 \pm 25 \\
185 \pm 34\end{array}$ & $\begin{array}{r}0 \\
-4\end{array}$ & $>0.5$ \\
\hline
\end{tabular}

* Standard deviation.

was $520 \mu$ Eq. per L., with a standard deviation of $145 \mu \mathrm{Eq}$. per L. By the fourth week of treatment (Figure 2) this value had risen significantly $(p<$ 0.01 ) to $1,020 \pm 316 \mu \mathrm{Eq}$. per L., a level comparable to that already described for subjects with spontaneous hyperthyroidism.

\section{DISCUSSION}

Glycogen depletion and rapid carbohydrate oxidation $(3,4,14)$ of hyperthyroid patients are such that, despite accelerated gluconeogenesis (3, 4), these subjects are particularly dependent upon fat as the major energy source. Within six hours

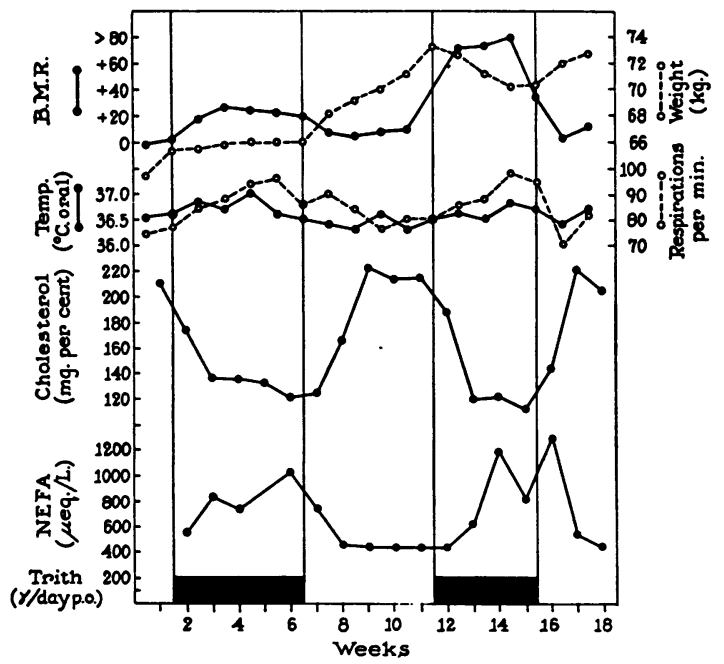

Fig. 3. Response of a Single Subject to Two Periods of Treatment with L-Triodothyronine (TRITH) of intravenous administration of TRITH, plasma NEFA rose to values in the range observed in naturally occurring or induced hyperthyroidism. This change appeared at the same time that accelerated heat production was first evident, in the absence of any alteration of blood glucose or cholesterol concentration and long before the fall of cholesterol or other blood lipids is known to occur (15). This suggests that the plasma NEFA rise is directly associated with accelerated mobilization and oxidation of fat necessary to support increased caloric output.

SUMMARY

1. Plasma nonesterified fatty acid (NEFA) concentration was found to be significantly increased when the basal metabolic rate was elevated in subjects with spontaneous and induced hyperthyroidism.

2. Euthyroid subjects showed an increased NEFA concentration within six hours after the intravenous administration of L-triiodothyronine, when accelerated oxygen consumption was first observed but before other signs or symptoms of hyperthyroidism appeared.

3. These results suggest that the increased plasma NEFA concentration reflects the accelerated mobilization of fat necessary to support the greater metabolic requirement of hyperthyroid subjects. 


\section{REFERENCES}

1. DuBois, E. F. Clinical colorimetry 14. Metabolism in exophthalmic goiter. Arch. intern. Med. 1916, 17, 915.

2. Sanger, B. J., and Hun, E. G. The glucose mobilization rate in hyperthyroidism. Arch. intern. Med. 1922, 30, 397.

3. Mirsky, I. A., and Broh-Kahn, R. H. The effect of experimental hyperthyroidism on carbohydrate metabolism. Amer. J. Physiol. 1936, 117, 6.

4. Karp, A., and Stettin, D., Jr. The effect of thyroid activity on certain anabolic processes studied with the aid of deuterium. J. biol. Chem. 1949, 179, 819.

5. Spirtes, M. A., Medes, G., and Weinhouse, S. A study of acetate metabolism and fatty acid synthesis in liver slices of hyperthyroid rats. J. biol. Chem. 1953, 204, 705.

6. Dole, V. P. A relation between non-esterified fatty acids in plasma and the metabolism of glucose. J. clin. Invest. 1956, 35, 150.

7. Gordon, R. S., Jr., and Cherkes, A. Unesterified fatty acid in human blood plasma. J. clin. Invest. 1956, 35, 206.

8. Bierman, E. L., Dole, V. P., and Roberts, T. N. An abnormality of nonesterified fatty acid metabolism in diabetes mellitus. Diabetes 1957, 6, 475.

9. Gordon, R. S., Jr. Unesterified fatty acid in human blood plasma. II. The transport function of unesterified fatty acid. J. clin. Invest. 1957, 36, 810.

10. Bierman, E. L., Schwartz, I. L., and Dole, V. P. Action of insulin on release of fatty acids from tissue stores. Amer. J. Physiol. 1957, 191, 359.

11. Gordon, R. S., Jr., and Cherkes, A. Production of unesterified fatty acids from isolated rat adipose tissue incubated in vitro. Proc. Soc. exp. Biol. (N. Y.) 1958, 97, 150.

12. Sperry, W. M., and Brand, F. C. The colorimetric determination of cholesterol. J. biol. Chem. 1943, 150, 315.

13. Nelson, N. A photometric adaptation of the Somogyi method for the determination of glucose. J. biol. Chem. 1944, 153, 375.

14. Sternheimer, R. The effect of a single injection of thyroxin on carbohydrates, protein and growth in the rat liver. Endocrinology 1939, 25, 899.

15. Sachs, B. A., Danielson, E., Isaacs, M. C., and Weston, R. E. Effect of triiodothyronine on serum lipids and lipoproteins of euthyroid and hyperthyroid subjects. J. clin. Endocr. 1958, 18, 506.

\section{SPECIAL NOTICE TO SUBSCRIBERS}

Post Offices will no longer forward the Journal when you move.

Please notify The Journal of Clinical Investigation, Business

Office, 333 Cedar Street, New Haven 11, Conn., at once when you have a change of address, and do not omit the zone number if there is one. 